\title{
Increasing The Brand Awareness of KONOPA to Its Customers through Instagram Account Management
}

\author{
Maichel Perdana Korompis \\ English Department, Faculty of Letters, Petra Christian University, Siwalankerto 121-131, Surabaya \\ 60236, INDONESIA \\ E-mail: maichel.perdana@gmail.com
}

\begin{abstract}
KONOPA or Komunitas Noken Papua is an official trade brand registered by the Papua Legal Department and Human Rights Department since 2011 located in Jayapura, Papua. KONOPA's main product is Noken, a multifunctional knotted or woven bag of Papuan. Unlike other online-based Noken sellers, KONOPA has its own production space in making Noken. However, I found that there was a lack of audience interaction in KONOPA's social media activity as well as the problem. After conducting an interview, the customers mostly were not interested in discovering the information KONOPA provided. Therefore, it is necessary to update the ways in promoting in order to increase consumer engagement. Thus, I designed some Instagram content and display pictures. These works would be beneficial for the organization to draw back the customers' attention and buy the products. Based on the final result as well as the solved problem, the average number of the audience interaction has increased.
\end{abstract}

Keywords: Brand awareness, Social Media Management, Instagram, Consumer Engagement

\section{INTRODUCTION}

KONOPA (Komunitas Noken Papua) is an independent organization located in Jayapura, Papua. It has been listed as an official trade brand registered by the Papua Legal Department and Human Rights Department since 2011. The main product of KONOPA is Noken, a traditional woven back from native Papuan that is knitted with the basic material of bark, roots, and leaves from trees, and it is traditionally used to carry various goods. KONOPA comes up from its purposes to preserve Noken's presence and be known as the best Noken craft center in Papua.

The result of my observation revealed a problem related to promotion in the Instagram account of KONOPA. The main problem that KONOPA faced was the lack of audience interaction in the social media activities. In Instagram, brand awareness can be measured through the performance of the consumer engagement. The consumer engagement is well known as actions taken by followers (customers) in the social media activities. The problem was identified from the performance of KONOPA's Instagram that has decreased. After conducting an interview with the customers, they mostly were not interested in discovering the contents and not convinced by the information given by KONOPA.

Accordingly, I decided to solve the problem to increase social interaction by making some interesting content works in its social media, Instagram. In order to increase the interaction, the works of the contents should attract the consumer interest. Technically I will hold KONOPA's Instagram account to update several posts by utilizing the features used on Instagram maximally.

These works would be beneficial for KONOPA to draw back its customers' attention and buy the products. The branding works will hopefully attract the customers to get to know KONOPA, its products as well as the organization identity, and it is easy for KONOPA to get 
customer loyalty to the products. Instagram management will also help KONOPA be more effective to raise its marketing strategy, especially in this digital era.

\section{LITERATURE REVIEW}

\section{Branding}

Branding is a combination of particular attributes that create differentiation of a product or organization which offers the products. The attributes include imagery, product photo / video, logo, packaging, tagline, and other visual features (Bonnici, 2015). Branding is a practical way to build a strong identity from a brand. Objectivity in branding is to introduce a brand in the competition of the marketplace.

\section{Marketing Communication}

Chris Fill and Barbara Jamieson (2016) found that Marketing Communication as an audience-centered community. They argued that Marketing Communication is a business practice that serves as a platform for businesses in presenting themselves to the audience/customer. Marketing Communication is the communication used in business carried out by organizations or individuals with the aim of achieving the marketing objectives. As we know, the definition of marketing is the most effective business practice for increasing the number of sales.

\section{Brand Awareness}

Brand awareness is a way for customers to identify the brand identity or meanings of the product (Spacey, 2017). During the interaction in value exchange, customers are able to recognize or recall a brand differently. Brand awareness plays a role as a key indicator of a brand's market performance. Thus, the indicator could be determined by some factors that affect the customer's minds such as the tagline, the product, the packaging, the appearance of the brand, ect. Not only attachment, the increase in the number of purchases can also be caused by increased brand awareness from customers.

\section{Unique Selling Point (USP)}

A product that can excel in comparison with hundreds and even thousands of other competitors is one that has a Unique Selling Point. USP is a factor that makes consumers choose one product over competitors such as the lowest cost, the highest quality, or the first-ever product of its kind (Rouse, 2013). In the long term, USP can differentiate between successful products and those that are not, because, if consumers had a reason to choose one product, they would keep purchasing and recommending it to others.

\section{SWOT Method}

When a company is about to start a business, it needs a planning process called a SWOT (Strength, Weakness, Opportunities, and Threats) analysis. In addition to determining the output of products, brand names, and budget, companies may also be able to determine where they should be compared with the kompetitor (Schooley, 2019). This is one of the many uses that a company might obtain when using a SWOT analysis, which would make it easier to arrange a strategy to determine business advantage over kompetitor.

In order to arrive into the USP, this method is needed to identify the collected data from both the brand and the customers. Technically, this technique will be used to describe the strengths, weaknesses, opportunities, and threats of KONOPA in the brand competition.

\section{Promotion and Its Tools}

Promotion is particular activities that refers to the company's efforts to communicate with current or potential customers about the products or services offered (Kokemuller, 2019). 
Korompis: Increasing The Brand Awareness of KONOPA to Its Customers through Instagram Account Management

Promotion is a form of marketing practice that seeks customers to become more familiar with one brand. Neil Kokemuller (2019) mentioned that there are five kinds of promotional tools which are differentiated based on the way they contribute to reach the customers and to achieve the communication objectives. They are traditional media, public relation, event, sales people / influencer, and digital Technology.

Most business people recently take advantage of digital technology to convey commercial messages of products or services they offered because the high attractiveness of a product or service is influenced by marketing activities delivered through social media. By recognizing the method that relates to customer behavior nowadays, social media will be a helpful promotion tool for me to do the project.

\section{Social Media}

As an online-based social networking service that functions as a platform for the users to exchange information, social media can have a significant influence on company brand awareness in society (Tritama and Tarigan, 2016). Social media is able to attract more customers as long as social media users are interested in the content displayed. The most dominant factor in influencing the attractiveness of customers to a brand or product is the success of content on social media. Commercial information can be conveyed through application platforms such as Facebook, Instagram, Youtube, etc.

Nowadays, brands are able to connect with their consumers through pictures or videos through online. This means that the content of the brand speaks on an emotional level that the words cannot explain through an online-based platform. From those social media application platforms, Instagram is a right platform at providing picture and video contents. Hence, this project is specifically run through this platform.

\section{Instagram}

Instagram is an online platform that enables its users to take and share interactive pictures and videos to other users. Many sources of inspiration, creative media, and great photographs can be found on this online platform (Frommer, 2010). The interactive relationships in Instagram can also be created between the brands and their consumers on Instagram. Its visual result allows brands to communicate their stories differently. Unlike brand, Instagram is a way where users get together to share and consume through particular interactive and original contents. Besides, brand plays a role as a "person" that is introduced by the marketer through Instagram (Hariadi, 2020).

Instagram Insights is an analytics tool that provides data on follower action. This tool is mostly used by marketers to measure the brand awareness through the performance of consumer engagement (Wright, 2018). Instagram consumer engagement has become the main purpose of brands or marketers (Hariadi, 2020). Technically, this tool will provide the users to describe the number of accounts reached. Users are able to measure the number of actions taken by the other users. In the end, in order to know the success of the works of this creative thesis, I will describe the comparison between the performance of KONOPA's Instagram account before and after doing this project.

In order to achieve the final result of this project, I planned several works to convey the messages. First of all, a profile is an important factor in increasing brand awareness because a profile is the audience's first impression of a brand (Njo, 2020). Instagram accounts need to be created effectively as well as an interactive profile display. Also, the graphic design and other symbols need to be designed as fascinating as possible so that consumers would feel familiar with the brand (Spacey, 2017). In Instagram profile display biography or better known as "Bio" is also an important point to get noticed. This way is called Digital Synchronization that 
aims to connect brands on Instagram to their information details or connect them with other online marketplaces and official websites (Hariadi, 2020). Therefore, I would manage the appearance of the profile display in order to build a better impression to the audience when discovering the brand.

Secondly, the contents of a brand absolutely has to be very interesting for consumers (Njo, 2020). If the product photos or videos are posted, the marketers should be as creative as possible in writing captions and using related hashtags in high quality and creative photography. Those ways could be done constantly to increase the possibility of consumers becoming more interested in the products or other contents posted. The content that the brand posts on feeds, Instagram Story, or IGTV would not mean anything if the consumers did not show their interest through likes, comments, and share the content to other Instagram users. On the other hand, the brands also need to pay attention to what they post as content in order to boost their consumer engagement. Therefore, I will work on several interesting contents as well as the communications works. The communications works would be divided into three sections; Introduction of the brand identity, renewal of catalogues display, and the representatif of Papuan Identity.

Last but not least, building brand awareness is a kind of Introducing a personal or individual. In order to be known by consumers, a brand needs to have "daily meetings" with consumers called branding (Hariadi, 2020). Viewers would be interested in a brand, if they are familiar with the brand itself. The more often the content appears on the Instagram page, the more consumers would feel familiar with the product. Thus, the brand's consumer engagement can rise with daily good-attractive content.

\section{METHOD}

A good interview is important so I can obtain large amounts of data in a short time. Through interviews, I learned more about problem conditions and real information taking place in the field. In this method, I used a semi-structured interview. I used guidelines that were not structured systematically and completely. The interview guide that I used was only an outline of the problem/context that would be asked. There were two parties who would be the interviewees. The first was the owner of KONOPA, Mr. Weriditi. The main reason I interviewed the owner was to get the valid information about the brand such as history, vision and mission, and desired expectations. The second party was the audience or the customers. Customers specifically provided me with several shortcomings that are not realized by KONOPA. Through the responses, they gave me a different point of view in creating a conclusion to the problem faced by KONOPA. In this practice, I selected 20 respondents who are customers who have followed KONOPA's Instagram account since three years ago. The respondents were people who were interested in contemporary culture and fashion.

Based on the interview, $70 \%$ of respondents do not buy the Noken products offered by KONOPA. A common reason that I found is the assumption that Noken is an ancient traditional product but has an expensive price. Besides, the dissemination of information about Noken products was not conveyed well so that some respondents did not get any interesting information. Noken products are not packaged attractively so they are not interested in buying them. Moreover, $55 \%$ of respondents know KONOPA only as Noken re-sellers. In addition, 85\% of respondents know Noken products as a symbol of Papuan cultural identity. Respondents who have Noken said the reason for using Noken is to show up an identity of Papuan. 
Korompis: Increasing The Brand Awareness of KONOPA to Its Customers through Instagram Account Management

After gathering the data from both the owner and the customers, I analyzed the data using the SWOT method, which resulted in the conclusion as the USP owned by KONOPA (Schooley, 2019).

\begin{tabular}{|c|c|}
\hline Strength & $\begin{array}{l}\text { - Special vision and mission in maintaining and empowering } \\
\text { - The modern-contemporary branding concept } \\
\text { - Led by an art and cultural worker } \\
\text { - } \text { Original quality of Noken product } \\
\text { - Have its own production }\end{array}$ \\
\hline Weakness & $\begin{array}{ll} & \text { The lack of brand management } \\
\text { - } & \text { Less references/knowledge in terms of promoting the brand }\end{array}$ \\
\hline Opportunity & $\begin{array}{l}\text { - Wide connection with other communities and agencies } \\
\text { - Registered as an official trademark at the Ministry of Law and Human } \\
\text { Rights, Papua Province } \\
\text { - Noken was recognized by UNESCO } \\
\text { - } 3,000 \text { more followers } \\
\text { Foreign buyer }\end{array}$ \\
\hline Threats & $\begin{array}{l}\text { - } \quad \text { Craftsmen no longer want to knit Noken } \\
\text { - The extinction of the main ingredients } \\
\text { - Craftsmen tend to use unoriginal component in knitting Noken as alternative }\end{array}$ \\
\hline
\end{tabular}

Finally, I arrived into the USP that will be helpful for me to recognize the Instagram works. The USPs of KONOPA could be found through the manufacturing process and the development of the brand itself. So far, KONOPA has established good relations with Noken craftsmen in the villages. Unlike other online-based Noken sellers, KONOPA is not a re-seller, but it is an independent organization that has its own production space in making the Noken products. Thus, KONOPA can ensure the quality of the Noken products they offered. Also, KONOPA is the only brand registered as an official trademark by the government in Papua. Considering that, all information provided by KONOPA would be trusted. In addition, the unique materials and cultural elements contained in the Noken also are the interesting points.

\section{FINDINGS AND DISCUSSIONS}

To accomplish this project, I worked on KONOPA's Instagram by designing the communication process in which the Instagram content. Based on the problem found, the communications process will be more focused in providing some interactives works. In designing the contents, the use of bilingual communications (English and Bahasa) would be added in the caption. The selection of features aims to maximize the work performance of social media management so that social media management can work effectively. The features that I will use later are Feed and Instastory. Furthermore, the upload process will be carried out in stages based on the timeline that has been created. To be recognized by the audience, KONOPA needs to have intense meetings with the audience. In this case, I will upload more or less every day in order to increase and maintain the intensif of the communication between KONOPA and the audience.

The communication process includes several works such as updating the profile display, the appearance of the brand identity, the catalog display, and additional content such as the representative of the Papuan identity.

\section{Profile Management}

In managing the KONOPA Instagram account, the basic thing I did for the first time was updating the appearance of KONOPA's Instagram profile. In the profile display, I modified and 
added some information in order to help the audiences to know the KONOPA brand clearly (Njo, 2020). These works were done through the title, the contact, website, Bio, and the brand logo. Changing the appearance of the logo is another factor that can raise the brand awareness of KONOPA (Spacey, 2013). I also changed the appearance of the logo that aims to show a new impression on KONOPA's Instagram account. In addition, I added a digital synchronization in the form of a link which will later be useful to make it easier for the audiences to communicate with KONOPA (Hariadi, 2020). This digital synchronization is LinkTree. It is a link that will automatically connect with other platforms such as WhatsApp, the Website and the online-shop site where KONOPA offers its Products. It technically will work as a bridge to maximize the communication flow between customers and KONOPA.
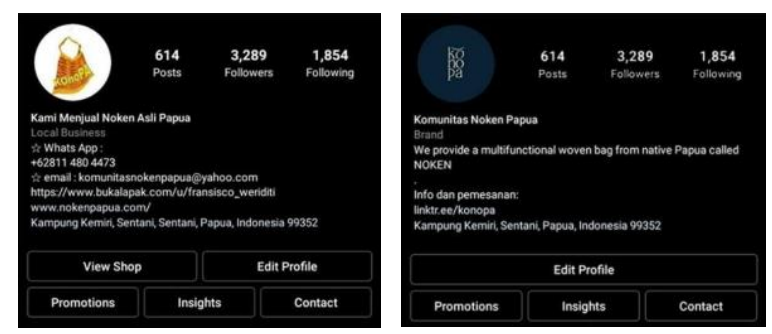

\section{Brand Identity}

Introducing the brand identity is the first step I would do in uploading the content on KONOPA Instagram account. This theme of content aims to sharpen the brand image or the USPs that were not previously conveyed by KONOPA (Bonnici, 2015). These contents will work as well as introducing the "personal" to the customers in order to make the audience familiar with the brand (Hariadi, 2020). In the communication process, the identity content is divided into several parts; introduction, vision-mission, the workshop in making Noken, and the closing statement as the Call to Action.

In the first part, I will upload one content as an introduction of the identity. The purpose of this content is to notify the audience about the presence of the identity in the future that will be packaged with a new way.

\begin{tabular}{|c|c|}
\hline VISUAL & DETAIL \\
\hline 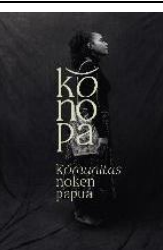 & $\begin{array}{l}\text { Caption: } \\
\text { This 4th December officially becomes one of our big celebrate for the world. It } \\
\text { begins from our proud of the old livings, then there grows a passion to hand } \\
\text { down the identity that reflects the behavior in living together }\end{array}$ \\
\hline 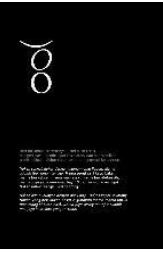 & $\begin{array}{l}\text { \#konopa \#papua \#komunitasnokenpapua \#identity \#brand \#harinokensedunia } \\
\text { \#harinoken \#harinoken \#nokenday \#traditionalbag \#wovenbag \#knottedbag } \\
\text { \#indonesia \#mamapapua } \\
\text { Due Date: } \\
\text { 4th December, } 2020\end{array}$ \\
\hline
\end{tabular}

The second part is the vision and mission. In uploading this content, I will upload a detailed explanation about KONOPA that has been running the brand since 2011. In other words, this content will describe the image of KONOPA. This vision-mission content aims to provide insight to the audience about what KONOPA is actually doing. 
Korompis: Increasing The Brand Awareness of KONOPA to Its Customers through Instagram Account Management

Next, I uploaded the BTS (behind the scene) of making a Noken. After describing KONOPA's vision and mission, I will also provide documentation about making Noken which aims to make the audience know more about Noken and know the process carried out by KONOPA.

In the last stage in this brand identity content, I will provide the closing content in the form of brand innovation that will be carried out by KONOPA. This content will be fully packaged into Call to Action content which aims to attract the audience to buy Noken offered by KONOPA.

\section{Catalog display}

This product content aims to sell the products. Through the work of these contents, I will upload some photo catalogs with better image quality and use models as additional displays (Njo, 2020). These contents would be devided into two; products with deatils and products with model. Thus, through the new display of the catalog, it will attract the interest of the audience to buy the Noken product.
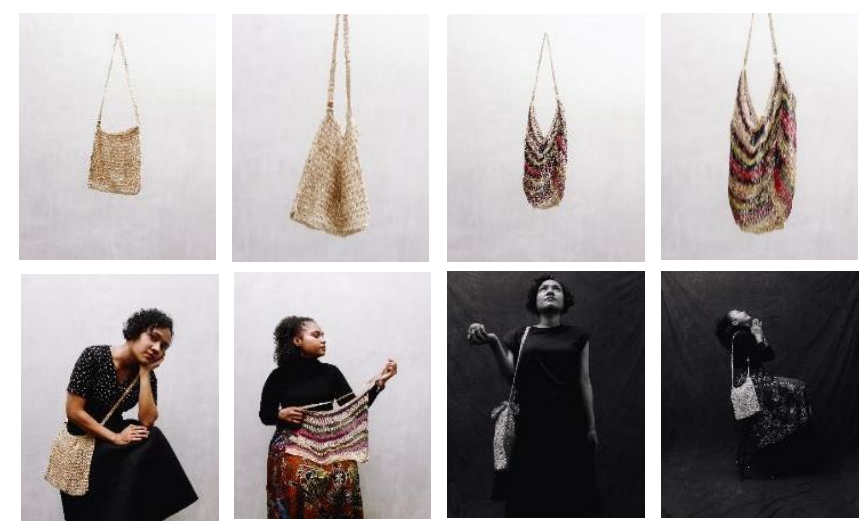

\section{Papuan Culture Representatives}

This content is additional content that serves as complementary content whose meaning will strengthen the brand identity of KONOPA. By presenting the cultural term of Papuan, it will sharpen the vision and mission that has been made by KONOPA. The cultural could be seen in the etnic of the model.

In order to arrive into the solution, I would compare between the number of Insight in the last 30 days before applying the works and the number of Insight after applying this projects works in three weeks. As well as the proven of the solved problem, it would describe the final result from the interaction number in Insight.

Before did the content works, I observed the overview in Insight of KONOPA Instagram account more or less in the last 30 days, I found that KONOPA Instagram account received impressions from 13,134 accounts randomly through the Instagram timeline. KONOPA has been reached by 1,730 other accounts for approximately one month. However, there were only 738 accounts that visit the profile of KONOPA Instagram account. The rest of them were not interesting to visit. Secondly, for the interaction of the contents, KONOPA only achieved 133 interactions. KONOPA had 118 interactions in feeds posted through 108 likes, 5 comments, and 5 saveds. For the Insta Story, KONOPA had only 15 interactions through 14 replies and 1 share.

After working on the contents and uploading it on Instagram within three weeks, the number of KONOPA Instagram Insights has increased. The number of impressions increased to 30,577 accounts. The number of account reached up to 2,674 accounts. While, the number of profile visits on KONOPA Instagram account raised among 1,384 accounts. After providing a link in Bio, it proved that there were 114 accounts who has continued to communicate with 
KONOPA for further information. Furthermore, the number of audience interactions increased to 883 interactions. The total interaction of all feed posts reaches 842 interactions through 788 likes, 8 comments, 25 saveds, and 21 shares. For the Instastory, KONOPA got 42 replies. Last but not least, the number of followers raised 50 followers in this project.

\section{CONCLUSION}

KONOPA has operated its Instagram account for approximately four years. However, there was a lack of audience interaction on KONOPA Instagram performance. After conducting an interview, the respondents mostly were not interested in discovering the contents. Common reasons found that the organization did not convey the customers well so that they did not get any interesting information. Also, Noken products are not packaged attractively so they are not interested in buying them. Therefore, in order to increase the performance of KONOPA's Instagram activity, it is necessary to update the ways in promoting through social media. The communication works technically were done through updating the profile display, introduction of the brand identity, the catalog display, and additional content that are relevant with the identity of KONOPA. After managing the Instagram of KONOPA for three weeks, the average number of the consumer engagement has increased as well as the solved problem. All contents and other technical activities can provide great benefits for KONOPA in terms of brand awareness. As it should be, the promotion of brand awareness through social media has been successful because the consumer engagement increased.

\section{REFERENCES}

Fill, C., \& Jamieson, B. (2016). Marketing Communications. Edinburg, UK: Heriot-Watt University

Frommer, Dan. (2010). Here's How To Use Instagram. Business Insider. Retrieved from https://www.businessinsider.com/instagram-2010-11?r=US\&IR=T

Hariadi, M. (2020, September 20). Personal interview [Personal interview]

Kokemuller, Neil. (2019). Marketing Promotional Tools. Chron. Retrieved from https://smallbusiness.chron.com/marketing-promotional-tools-60473.html

Latif, W. B., Islam, M. A., \& Mdnoor, I. (2015). Building Brand Awareness in the Modern Marketing Environment: A Conceptual Model. International Journal of Business and Technopreneurship, 4, 69-82.

Njo, S.O.T. (2020, September 05). Personal interview [Personal interview]

Rouse, Margaret (2013). Unique Selling Point (USP). TechTarget. Retrieved from https://whatis.techtarget.com/definition/unique-selling-point-USP

Sammut-Bonnici, Tanya. (2015). Brand and Branding. Wiley Encyclopedia of ManagementStrategic Management, 12. 
Korompis: Increasing The Brand Awareness of KONOPA to Its Customers through Instagram Account Management

Schooley, Skye. (2019). SWOT Analysis: What It Is and When to Use It. Business News Daily. Retrieved from https://www.businessnewsdaily.com/4245-swot-analysis.html

Spacey, John. (2017). 5 Types of Brand Awareness. Simplicable. Retrieved from https://simplicable.com/new/brand-awareness

Tritama, H. B., \& Tarigan, R. E. (2016). The Effect of Social Media to The Brand Awareness of A Product of A Company. International Journal of Communication \& Information Technology, 10, 9-114.

Wright, Victoria. (2018). 4 Ways to Use Instagram Insights to Improve Your Marketing. Social Media Examiner. Retrieved from https://www.socialmediaexaminer.com/4-ways-touse-instagram-insights-to-improve-marketing/ 